\title{
Cultured Human Liver Fat-storing Cells Produce Monocyte Chemotactic Protein-1 Regulation by Proinflammatory Cytokines
}

\author{
Fabio Marra, Anthony J. Valente, * Massimo Pinzani, ${ }^{\star}$ and Hanna E. Abboud \\ Departments of Medicine and *Pathology, The University of Texas Health Science Center at San Antonio, \\ San Antonio, Texas 78284-7882; and ${ }^{\ddagger}$ Clinica Medica II, University of Florence, I-50134 Florence, Italy
}

\begin{abstract}
Monocytes infiltrate the portal space during chronic liver inflammation. Monocyte chemotactic protein-1 (MCP-1) is a cytokine that induces monocyte chemotaxis and activation. We investigated if human liver fat-storing cells (FSC) secrete MCP-1, and the mechanisms that regulate MCP-1 production. Unstimulated FSC secrete MCP-1 as measured by radioimmunoassay as well as a chemotactic assay and express mRNA that encodes for this cytokine. A two- to threefold increase in MCP1 secretion was observed when FSC were treated with either interleukin-1 $\alpha$ (IL-1 $\alpha)$ or interferon- $\gamma($ IFN- $\gamma)$. Tumor necrosis factor- $\alpha$ (TNF $\alpha)$ also increased MCP-1 secretion, although to a lesser extent (1.6-fold). Northern blot analysis showed that IL-1 $\alpha$ and IFN- $\gamma$ strongly increase the levels of mRNA that encodes for MCP-1, whereas TNF $\alpha$ appears to be a weaker stimulus. Analysis of FSC-conditioned medium by sodium dodecyl sulfate-polyacrylamide gel electrophoresis and immunoblotting revealed three bands of MCP-1 that most likely represent isoforms of different apparent molecular weights. Pretreatment of FSC with $\mathrm{H}-7$, a protein kinase $\mathrm{C}$ inhibitor, blocked cytokine-induced increase in both MCP-1 gene expression and secretion. To determine the potential role of MCP-1 in vivo, we also analyzed normal and pathologic human liver tissue. Northern blot analysis showed that MCP-1 mRNA expression is more abundant in liver tissue obtained from patients with chronic active hepatitis compared with normal liver tissue. These studies indicate that MCP-1 secreted by FSC is stimulated by proinflammatory cytokines and that MCP-1 gene expression is upregulated in chronic inflammatory liver disease. MCP-1 released by FSC may participate in the recruitment and activation of monocytes at sites of liver injury. (J. Clin. Invest. 1993.92:1674-1680.) Key words: inter-
\end{abstract}

Portions of this work were presented at the 43rd Meeting of the American Association for the Study of Liver Disease, Chicago, IL (October 31-November 3, 1992) and published in abstract form (1992. Hepatology. 16:100a [Abstr.]).

Address correspondence to Dr. Hanna E. Abboud, Department of Medicine, University of Texas Health Science Center at San Antonio, 7703 Floyd Curl Drive, San Antonio, TX 78284-7882.

Received for publication 30 November 1992 and in revised form 17 May 1993.

1. Abbreviations used in this paper: FSC, fat-storing cells; MCP-1, monocyte chemotactic protein-1; PDGF, platelet-derived growth factor; TNF $\alpha$, tumor necrosis factor- $\alpha$.

J. Clin. Invest.

(c) The American Society for Clinical Investigation, Inc.

0021-9738/93/10/1674/07 \$2.00

Volume 92, October 1993, 1674-1680 leukin-1 $\alpha \bullet$ interferon- $\gamma \bullet$ tumor necrosis factor $\alpha \bullet$ platelet-derived growth factor $\bullet$ protein kinase $\mathbf{C}$

\section{Introduction}

Infiltration of the portal tract by mononuclear cells is a common histologic abnormality during chronic liver inflammation. Mononuclear cells penetrate the hepatic lobule and contribute to the eventual formation of liver fibrosis and cirrhosis (1). Understanding the mechanisms leading to cell infiltration in the injured liver is potentially relevant for understanding the pathogenesis of chronic liver disease. Studies addressing this issue are lacking. Recruitment of phagocytes in response to infection or tissue damage occurs through generation of chemotactic gradients that attract inflammatory cells to the site of injury. A novel family of proinflammatory proteins that are able to specifically affect the migration of a single class of leukocytes has recently been identified (2). A subclass of this group of cytokines, referred to as C-X-C, based on the position of two conserved cysteine residues, includes the granulocyte chemoattractant IL-8. Human monocyte chemotactic protein1 (MCP-1 $)^{1}$ belongs to the subclass $\mathrm{C}-\mathrm{C}$, in which the two cysteine residues are adjacent. MCP-1 is a 76-amino acid monomeric peptide that exerts chemoattractant activity for monocytes but not for neutrophils or lymphocytes, which lack MCP-1 receptors (3). This molecule is identical to the monocyte chemoattractant produced by primate vascular smooth muscle cells and named smooth muscle cell-derived chemotactic factor (4). MCP-1 accounts for most of the chemotactic activity secreted by tumor cells and nontransformed cells in culture (5-7). Molecular cloning and sequencing of the MCP1 gene has been reported (8).

Liver fat-storing cells (FSC), also called lipocytes, Ito cells, or stellate cells, are liver-specific sinusoidal pericytes characterized by intracytoplasmic lipid vacuoles containing vitamin A (9-13). These cells are the major source of collagen production in the fibrotic liver (14-16). They are considered to play a pivotal role in the pathogenesis of liver fibrosis through a transition from a "quiescent" fat-storing phenotype to an "activated" myofibroblast-like appearance (17). When liver FSC are plated on plastic, they proliferate and undergo a phenotypic modification that closely resembles that occurring in vivo during liver fibrosis. This includes loss of vitamin A granules, hypertrophy of rough endoplasmic reticulum, expression of smooth muscle $\alpha$-actin, and a switch in the pattern of collagen types produced (18-23).

In the present study, we report that cultured human liver FSC secrete MCP-1, and that the proinflammatory cytokines IL- $1 \alpha$, IFN- $\gamma$, and tumor necrosis factor- $\alpha$ (TNF $\alpha)$ induce the production of this monocyte chemoattractant through a protein kinase C-dependent pathway. Furthermore, MCP-1 gene expression is upregulated in tissue from patients with chronic liver disease. 


\section{Methods}

Reagents. Recombinant human IL- $1 \alpha$ and IFN $\gamma$ were purchased from Collaborative Biomedical Products (Bedford, MA); recombinant human TNF $\alpha$ was purchased from R\&D Systems (Minneapolis, MN); recombinant human platelet-derived growth factor (PDGF) BB was purchased from Amgen Biologicals (Thousand Oaks, CA); H-7 (1-[5isoquinolinesulfonyl]-2-methylpiperazine) was purchased from $\mathrm{Cal}$ biochem-Behring Corp. (San Diego, CA). Maximal levels of endotoxin in the cytokine preparations used in the present study were always $<5$ $\mathrm{pg} / \mathrm{ml}$ (final concentration). In separate experiments, we found that endotoxin concentrations as high as $1 \mu \mathrm{g} / \mathrm{ml}$ do not increase MCP-1 production in human liver FSC.

Isolation and culture of human liver FSC. Human liver FSC were isolated from wedge sections of normal human liver tissue unsuitable for transplantation, as described elsewhere (13). Briefly, finely minced liver tissue was digested with $0.5 \%$ pronase, $0.05 \%$ type IV collagenase, and $10 \mu \mathrm{g} / \mathrm{ml}$ DNAse, filtered through a $105-\mu \mathrm{m}$ nylon gauze, washed, and resuspended in HBSS. FSC were separated from other nonparenchymal cells by ultracentrifugation over gradients of stractan (Larex Co., Tacoma, WA ). Cells were cultured on plastic tissue culture dishes in Waymouth's medium (Gibco Laboratories, Grand Island, NY) supplemented with $0.6 \mathrm{U} / \mathrm{ml}$ insulin, $2 \mathrm{mM}$ L-glutamine, $0.1 \mathrm{mM}$ nonessential aminoacids, $1 \mathrm{mM}$ sodium pyruvate, antibiotic antifungal solution, and $17 \%$ FCS. Cells in primary and passaged cultures were characterized by immunohistochemistry and transmission electron microscopy as described elsewhere (13). Cells were subcultured when confluent at 1:3 split ratio and used between passages four and nine. Phase contrast and electron microscopic analysis at these stages revealed a complete transition to the myofibroblast-like phenotype. Data presented herein were obtained using two separate cell lines.

Determination of MCP-1 levels in conditioned medium. Cells were subcultured in multiwell dishes to near-confluence, washed twice with HBSS, and incubated in serum-free insulin-free medium under the conditions to be tested for the time periods indicated. Cell-conditioned medium was clarified by centrifugation at $10,000 \mathrm{~g}$ for $2 \mathrm{~min}$, and stored at $-70^{\circ} \mathrm{C}$ until assayed. Cells were trypsinized, and the number of cells in each well was determined using a cell counter (Coulter Electronics, Hialeah, FL).

A radioimmunoassay for MCP-1 was developed using salt precipitation to separate bound from free labeled MCP-1. Highly purified human MCP-1 (15,000-mol wt form) was isolated from serum-free conditioned medium of the human U 105 tumor cell line using a procedure described earlier (4). 2-5 $\mu \mathrm{g}$ of the purified protein was labeled with ${ }^{125} \mathrm{I}$ using the Bolton-Hunter reaction as described previously (24). Specific activities of $100-300 \mathrm{cpm} / \mathrm{pg}$ protein were routinely obtained. Protein-associated counts were $90 \%$ precipitable in $10 \%$ TCA. In a preliminary study it was determined that sodium sulfate at a final concentration of $14-15 \%$ (wt/ vol) would precipitate $<10 \%$ of ${ }^{125} \mathrm{I}-\mathrm{MCP}-1$ in the presence of nonimmune serum, whereas $>90 \%$ could be precipitated after reaction with a 1:100 dilution of a specific rabbit antiserum to baboon MCP-1. Based on these observations, the following standard protocol was adopted for a radioimmunoassay. To $150 \mu \mathrm{l}$ volume of the test solution in disposable $12 \times 75-\mathrm{mm}$ borosilicate test tubes was added $50 \mu \mathrm{l}$ of ${ }^{125} \mathrm{I}-\mathrm{MCP}-1\left(3 \times 10^{5} \mathrm{cpm} / \mathrm{ml}\right.$ in assay buffer: $150 \mathrm{mM}$ $\mathrm{NaCl}, 10 \mathrm{mM}$ Tris-Cl, pH 8.0, $1 \mathrm{mM}$ EDTA, $0.5 \% \mathrm{HSA}$ ), and $100 \mu \mathrm{l}$ of the rabbit antibody to MCP-1 (diluted 1:500 in assay buffer). The tubes were incubated at $37^{\circ} \mathrm{C}$ for $2 \mathrm{~h}$, then $100 \mu \mathrm{l}$ of calf serum (carrier) and $1 \mathrm{ml}$ of $19.6 \%$ sodium sulfate were added and incubation was continued for $30 \mathrm{~min}$ at room temperature. The tubes were centrifuged at $1,500 \mathrm{~g}$ for $15 \mathrm{~min}$, the supernatant discarded, and the activity in the precipitate counted. All determinations were made in duplicate; replicate values varied by $<10 \%$. Under these conditions, $\sim 60 \%$ of the total added counts were bound maximally $\left(B_{0}\right)$. Pooled serum-free medium (DMEM with antibiotics) conditioned by cultured human $\mathrm{U} 105$ cells for $3 \mathrm{~d}$ was used as a working standard. Unlike recombinant material, MCP-1 secreted by U 105 cells is glycosylated, and is therefore a more suitable standard for RIA. The medium was filtered $(0.2 \mu \mathrm{m})$ and stored in aliquots at $-70^{\circ} \mathrm{C}$. Aliquots were thawed and used once. Dilutions of the standard were made in assay buffer and determinations made in triplicate. A typical standard curve is shown in Fig. 1. Each working standard pool $(60-80 \mathrm{ng} / \mathrm{ml} \mathrm{MCP}-1)$ is standardized with freshly prepared highly purified MCP-1 quantitated as previously described (4). The purity of the purified MCP-1 was determined by SDS-PAGE and silver staining. The limit of detection of this assay was $\sim 5 \mathrm{ng} / \mathrm{ml} \mathrm{MCP}-1$. The range of the standard curve was $5-70 \mathrm{ng} / \mathrm{ml}$ (see Fig. 1). When necessary, test samples were diluted in assay buffer to bring them into this range.

Monocyte chemotactic activity. Near confluent FSC were incubated in serum-free, insulin-free medium for $48 \mathrm{~h}$. The medium was then removed, clarified by centrifugation at $10,000 \mathrm{~g}$ for $2 \mathrm{~min}$, and stored at $-70^{\circ} \mathrm{C}$ until assayed. Chemotaxis assays were carried out with freshly prepared human blood mononuclear cells essentially as described previously (25). Briefly, blood anticoagulated with acid-citrate-dextrose was centrifuged at $150 \mathrm{~g}$ for $20 \mathrm{~min}$ at $4^{\circ} \mathrm{C}$ to remove platelet-rich plasma. The cells were resuspended to twice the original blood volume in $\mathrm{Ca}^{2+}$. and $\mathrm{Mg}^{2+}$-free HBSS supplemented with $2.7 \mathrm{~g} / 1$ dextrose and $3.7 \mathrm{~g} / 1$ trisodium citrate (HBSS-CD) and the centrifugation step repeated. The cells were again resuspended to twice the original blood volume in HBSS-CD and layered over 1 vol of Histopaque 1077 (Sigma Chemical Co., St. Louis, MO) and centrifuged at $750 \mathrm{~g}$ for $30 \mathrm{~min}$ at $4^{\circ} \mathrm{C}$. The mononuclear cells at the interface were aspirated, washed twice in HBSS-CD, and resuspended in assay medium (DMEM $+0.5 \%$ HSA) to $3.0 \times 10^{6} \mathrm{cells} / \mathrm{ml}$. Mononuclear cell preparations were $>95 \%$ viable as determined by trypan blue exclusion. Monocyte chemotaxis was carried out in modified (blind-well) Boyden chambers using polyvinylpyrrolidone-free 5- $\mu \mathrm{m}$-pore polycarbonate filters (Poretics Corp., Livermore, CA). Samples to be assayed were diluted in assay medium or adjusted to $0.5 \%$ HSA by the addition of $25 \%$ HSA, and $100-\mu 1$ samples were placed in the wells below the filters. For neutralization experiments, samples were preincubated for $60 \mathrm{~min}$ at $37^{\circ} \mathrm{C}$ with rabbit antiserum to MCP-1 diluted 1:200. $200 \mu \mathrm{l}$ of the mononuclear cell preparations was placed above the filters, and the chambers were incubated at $37^{\circ} \mathrm{C}$ in $5 \% \mathrm{CO}_{2}$ for $90 \mathrm{~min}$. The filters were removed, fixed in methyl alcohol, and stained with Giemsa. Cells migrating to the underside of the filters were quantitated by light microscopy and the mean number of cells in 10 high-power $(\times 100)$ fields was calculated.

Determination of MCP-1 mRNA levels. Confluent cell monolayers were incubated in serum-free, insulin-free medium for $48 \mathrm{~h}$ and stimu-

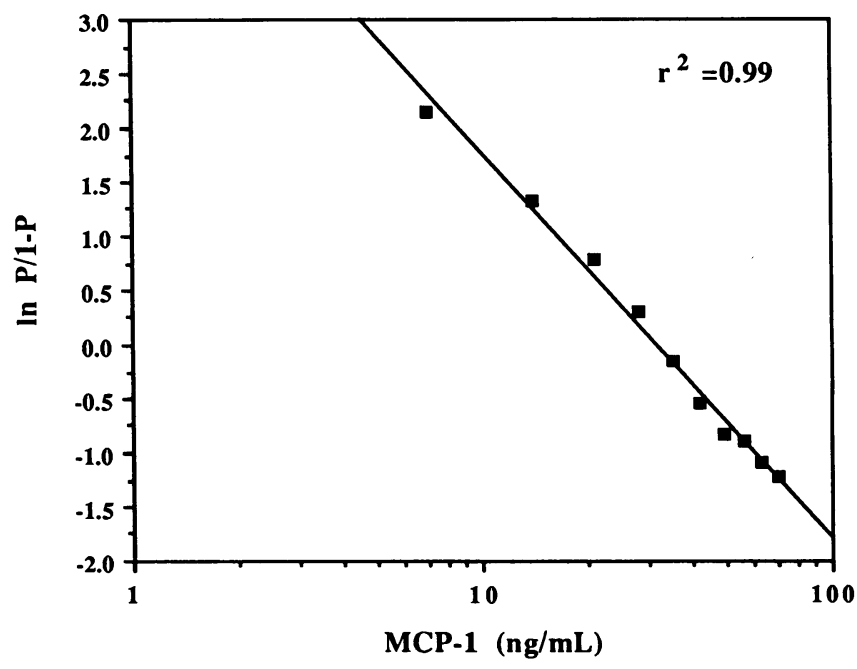

Figure 1. A standard curve of MCP-1 radioimmunoassay. Standard MCP-1 was prepared as described in Methods. Each point is the mean of triplicate determinations. $P$ indicates the ratio of $\left[{ }^{125} \mathrm{I}\right] \mathrm{MCP}-1$ bound in the presence of competitor to [ $\left.{ }^{125} \mathrm{I}\right] \mathrm{MCP}-1$ bound in the absence of competitor (total bound to antibodies). 
Table I. Monocyte Chemotactic Activity in FSC-conditioned Medium

\begin{tabular}{lc}
\hline \multicolumn{1}{c}{ Condition } & Monocyte chemotaxis \\
\hline & cells/high-power field \\
Buffer alone & $5.4 \pm 1.8$ \\
$\begin{array}{l}\text { FSC-conditioned medium } \\
\text { FSC-conditioned medium }+1: 200 \\
\text { anti-MCP-1 serum }\end{array}$ & $44.3 \pm 5.1$ \\
& \\
\hline
\end{tabular}

Human liver FSC were grown to confluence and incubated in serumfree medium for $48 \mathrm{~h}$. Monocyte chemotactic activity was quantitated as described in Methods. Data are mean \pm SD of triplicate determinations.

lated as indicated. RNA was isolated by one-step guanidinium thiocyanate-phenol chloroform extraction as described by Chomczynski and Sacchi (26). The amount of RNA was determined by measuring 260 $\mathrm{nm}$ absorbance. RNA quantitation was confirmed by $1 \%$ agarose gel electrophoresis and ethidium bromide staining. Total RNA was fractionated by electrophoresis on a $1 \%$ agarose-formaldehyde gel, and blotted on a nylon membrane (GeneScreen; New England Nuclear, Boston, MA). $25 \mathrm{ng}$ of a baboon MCP-1 cDNA probe was labeled by random priming using a commercial kit (Amersham Co., Arlington Heights, IL $)$ and $\left[{ }^{32} \mathrm{P}\right] \mathrm{dCTP}(3,000 \mathrm{Ci} / \mathrm{mmol}$; New England Nuclear $)$. Specific activity of the labeled probe was always $>10^{9} \mathrm{cpm} / \mu \mathrm{g}$. Filters were baked and prehybridized for $1 \mathrm{~h}$ before hybridization overnight with $2 \times 10^{6} \mathrm{cpm} / \mathrm{ml}$ of labeled probe. Blots were then washed and autoradiographed using a X-OMAT AR film (Kodak, Rochester, NY). After removal of the MCP-1 probe, the same filters were hybridized with a ${ }^{32} \mathrm{P}$-labeled probe encoding for the ribosomal protein 36B4 (27).

Characterization of $M C P-1$ protein. Serum-free insulin-free medium $(40 \mathrm{ml})$ conditioned for $72 \mathrm{~h}$ by cultured FSC was precipitated by addition of $3 \mathrm{vol}$ of cold acetone at $-20^{\circ} \mathrm{C}$ for $2 \mathrm{~h}$. The precipitate was collected by centrifugation at $4,000 \mathrm{~g}$ for $10 \mathrm{~min}$, resuspended in $10 \mathrm{ml}$ distilled water, and lyophilized. The lyophilized material was dissolved in $5 \mathrm{ml} \mathrm{PBS}$ with stirring for $30 \mathrm{~min}$ at $4^{\circ} \mathrm{C}$ and the solution clarified by centrifugation on a microcentrifuge for $5 \mathrm{~min}$ and filtration through a $0.2-\mu \mathrm{m}$ filter. A semipurified protein fraction of this solution was obtained by reverse-phase HPLC. Specifically, the entire solution was applied to a Vydac $10 \times 250$-mm protein $\mathrm{C} 4$ column equilibrated in $0.1 \%(\mathrm{vol} / \mathrm{vol})$ trifluoroacetic acid and eluted with a linear gradient of acetonitrile in $0.1 \%$ trifluoroacetic acid at $2 \mathrm{ml} / \mathrm{min}$. Proteins eluting in $25-35 \%(\mathrm{vol} / \mathrm{vol})$ acetonitrile were pooled and lyophilized. The lyophilized protein was dissolved in $0.5 \mathrm{ml}$ deionized water and an aliquot mixed with an equal volume of $2 \times$ SDS-PAGE loading buffer (reducing) and boiled for $2 \mathrm{~min}$. SDS-PAGE was carried out in 15\% acrylamide mini-gels using a discontinuous buffer system (28). After separation, the proteins were transferred to nitrocellulose membrane using a semi-dry transfer cell (Trans-Blot SD; Bio-Rad Laboratories, Richmond, CA). Immunostaining of MCP-1 was carried out in $0.5 \mathrm{M}$ $\mathrm{NaCl}, 0.02 \mathrm{M}$ Tris- $\mathrm{HCl}, \mathrm{pH} 7.6$ (TBS) containing $5 \%$ dried milk as a blocking agent. The membrane-bound proteins were reacted in sequence for $60 \mathrm{~min}$ with rabbit antiserum to baboon MCP-1 (1:500 dilution), which cross-reacts completely with human MCP-1, goat anti-rabbit IgG ( $1: 50$ dilution), and peroxidase-antiperoxidase (1:500 dilution) ( rabbit PAP; Sigma Chemical Co.). The blot was washed for $30 \mathrm{~min}$ in three changes of TBS between reactions. The peroxidase color reaction was developed with 4-chloro-1-naphthol using the suppliers protocol (Bio-Rad Laboratories). The blots were calibrated with biotinylated protein molecular weight markers (Sigma Chemical Co.) that were reacted with streptavidin-peroxidase (1:500) added during the peroxidase-antiperoxidase incubation step.
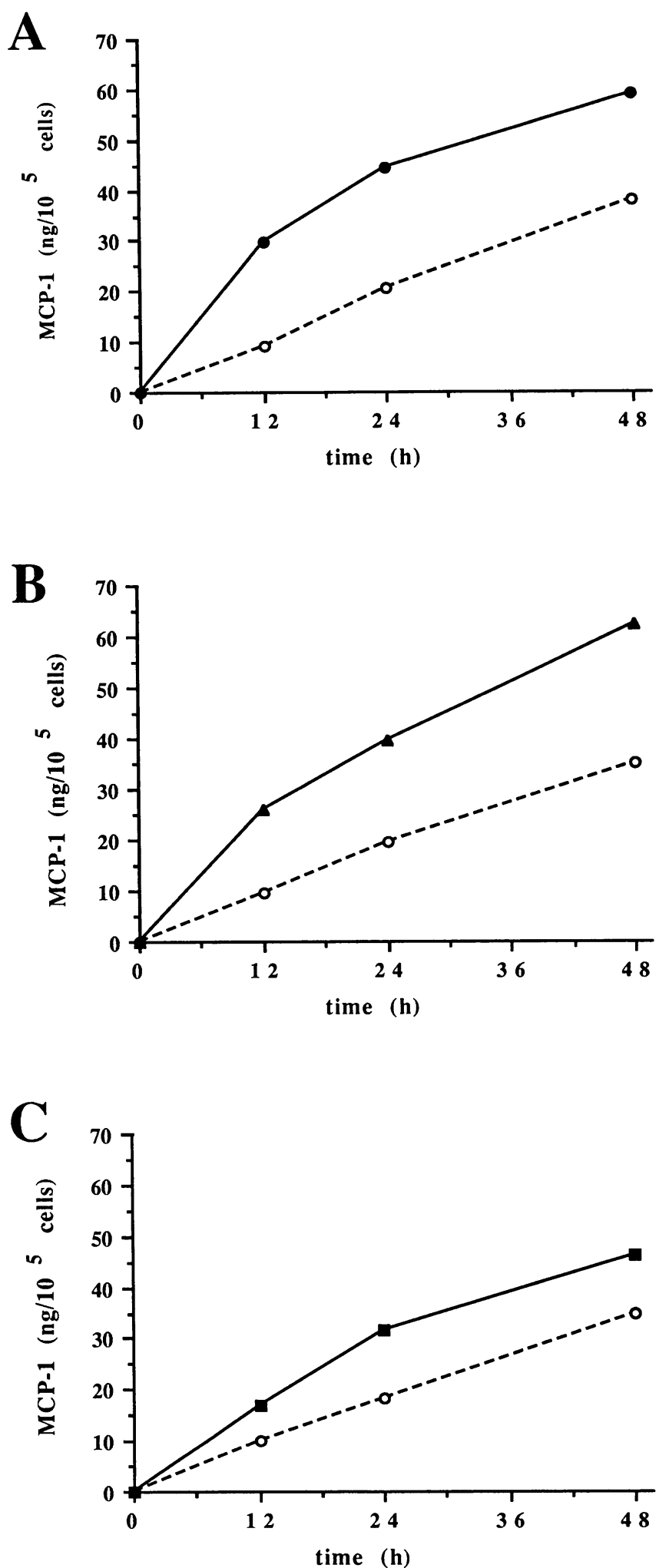

Figure 2. Unstimulated and stimulated secretion of MCP-1 by cultured FSC. Confluent human liver FSC were incubated in serum-free, insulin-free medium for the time periods indicated, in the absence (dashed lines) or in the presence (solid lines) of $(A) \mathrm{IL}-1 \alpha, 25 \mathrm{U} / \mathrm{ml}$; (B) IFN- $\gamma, 1,000 \mathrm{U} / \mathrm{ml}$; or $(C) \mathrm{TNF} \alpha, 25 \mathrm{U} / \mathrm{ml}$. MCP-1 concentration in cell-conditioned medium was measured by RIA. Cell counts were obtained from the same wells at the end of each collection period. Shown are experiments carried out in duplicate. Range of the variation between two measurements was always $<13 \%$ 
In vivo MCP-1 gene expression. Normal liver tissue was obtained from surgical biopsies carried out in two patients undergoing cholecystectomy. Normal liver structure was shown in these specimens by routine histology. Liver biopsy specimens were obtained from four patients (three males, one female; age range, 21-54 yr) with elevated serum alanine aminotransferase ( mean $\pm \mathrm{SD}, 145 \pm 33 \mathrm{U} / \mathrm{l}$; range, 113 190; normal values, < $40 \mathrm{U} / 1$ ) and clinical features suggesting chronic liver disease. Etiology of hepatitis was chronic hepatitis $\mathrm{C}$ virus (HCV) infection in three cases, and chronic hepatitis B virus (HBV) infection in one case. Informed consent was given by all subjects. The specimens (minimal size, $\sim 20 \mathrm{~mm}$ in length and $\sim 1.6 \mathrm{~mm}$ in diameter) were obtained with a SureCut biopsy needle (HS Hospital Service, Rome, Italy). Approximately half of each specimen was immediately frozen in liquid nitrogen and stored at $-80^{\circ} \mathrm{C}$ until used for RNA extraction. The specimens were also processed for routine histological examination, which revealed typical features of chronic active hepatitis in all patients. These included an abundant inflammatory infiltrate in the portal spaces spreading into the hepatic lobule with evidence of intralobular necrosis and fibrosis. RNA was prepared according to Chomczinsky and Sacchi (26). $20 \mu \mathrm{g}$ of total RNA was loaded on an agarose formaldehyde gel and Northern blot analysis was performed as described above, except that ethidium bromide staining of the gel was performed before the transfer of RNA to nylon membrane, to ensure equal RNA loading.

Statistical analysis. Comparison of MCP-1 secretion measured in the presence or in the absence of the PKC inhibitor was performed by Student's $t$ test for paired data.

\section{Results}

Unstimulated human liver FSC in culture secrete detectable amounts of MCP-1 after $12 \mathrm{~h}$ of incubation in serum-free insulin-free medium. After a 24-h incubation, the average secretion of MCP-1 ( \pm SD) was $20.9 \pm 3.6 \mathrm{ng} / 10^{5}$ cells as measured by a sensitive and specific RIA. FSC-conditioned medium also ex-

\section{IL-1 $\alpha(10 \mathrm{U} / \mathrm{mL})$}
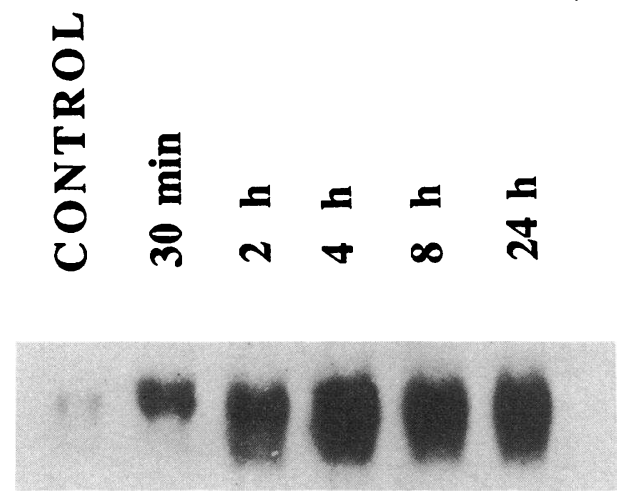

MCP-1 $-0.7 \mathrm{~Kb}$
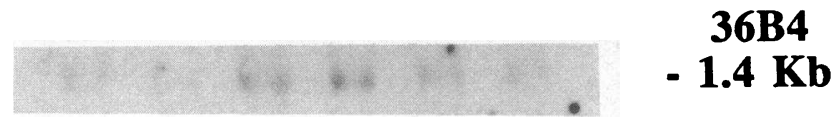

Figure 3. Northern blot analysis of MCP-1 gene expression in response to IL- $1 \alpha$ in human FSC. Confluent human FSC were incubated in serum-free, insulin-free medium for $48 \mathrm{~h}$, followed by the addition of recombinant human IL- $1 \alpha$ for the indicated time periods. At the end of the incubation, RNA was prepared from cell lysates as described in Methods. For Northern blot analysis, $15 \mu \mathrm{g}$ of total RNA was fractionated on a $1 \%$ agarose-formaldehyde gel, blotted on a nylon membrane, and hybridized with a baboon cDNA encoding for MCP-1. The same filters were washed and hybridized with a probe encoding for the ribosomal protein 36B4.

\section{IFN- $\gamma(1000 \mathrm{U} / \mathrm{mL})$}

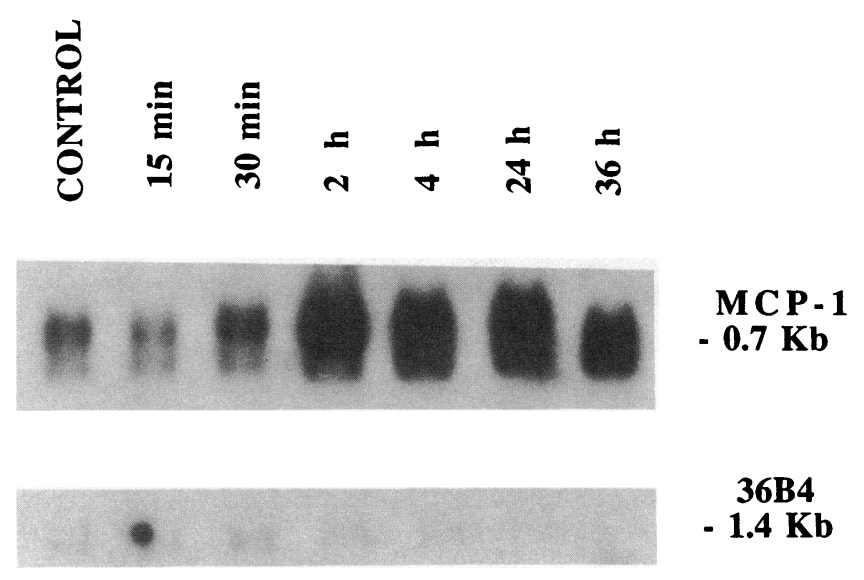

Figure 4. Northern blot analysis of MCP-1 gene expression in response to IFN- $\gamma$ in human FSC. Confluent human FSC were incubated in serum-free, insulin-free medium for $48 \mathrm{~h}$ and incubated with recombinant human IFN- $\gamma$ for the indicated time periods. Northern blot analysis was performed as described in the legend to Fig. 3.

erts monocyte chemotactic activity that can be largely accounted for by MCP-1 since it was blocked $>80 \%$ by an antiMCP-1 antibody in a chemotactic assay (Table I). Proinflammatory cytokines stimulate MCP-1 protein secretion. Fig. 2 shows a time course for the effects of IL- $1 \alpha(25 \mathrm{U} / \mathrm{ml})$, IFN- $\gamma$ $(1,000 \mathrm{U} / \mathrm{ml})$, or TNF $\alpha(25 \mathrm{U} / \mathrm{ml})$ on MCP-1 accumulation in serum-free, insulin-free medium. A two- to threefold increase in MCP-1 secretion was observed in response to both IL- $1 \alpha$ (Fig. $2 A$ ) and IFN- $\gamma$ (Fig. $2 B$ ) as early as $12 \mathrm{~h}$ after cytokine addition. Increased levels persisted for at least $48 \mathrm{~h}$. $\mathrm{TNF} \alpha(25 \mathrm{U} / \mathrm{ml})$ also stimulated MCP-1 production, although to a lesser extent compared with both IL- $1 \alpha$ and IFN- $\gamma$ (Fig. $2 C$ ). The mean $( \pm \mathrm{SD})$ increase in $24-\mathrm{h} \mathrm{MCP}-1$ production was 2.01 $\pm 0.46-, 2.07 \pm 0.69-$, and 1.64 \pm 0.45 -fold over basal values after stimulation with IL- $1 \alpha(25 \mathrm{U} / \mathrm{ml})$, IFN- $\gamma$ $(1,000 \mathrm{U} / \mathrm{ml})$, or TNF $\alpha(25 \mathrm{U} / \mathrm{ml})$, respectively. The increase in MCP-1 secretion was dose dependent in response to all three cytokines, and concentrations as low as $1 \mathrm{U} / \mathrm{ml}$ of IL- $1 \alpha$ or $100 \mathrm{U} / \mathrm{ml}$ of IFN- $\gamma$ were able to induce submaximal increases in MCP-1 secretion by FSC, whereas a concentration of $100 \mathrm{U} / \mathrm{ml}$ of TNF $\alpha$ was required to achieve maximal stimulation.

Northern blot analysis of steady-state mRNA levels revealed that unstimulated, serum-deprived FSC express low levels of MCP-1 gene (Figs. 3-5). The time course of MCP-1 gene expression after stimulation with IL- $1 \alpha$, IFN- $\gamma$, or TNF $\alpha$ is shown in Figs. 3-5. An increase in the levels of mRNA encoding for MCP-1 was observed after a 4-h stimulation with IL-1 $\alpha$ (Fig. 3) or IFN- $\gamma$ (Fig. 4). Also, TNF $\alpha$ induced MCP-1 gene expression, although to a lesser extent when compared with both IL- $1 \alpha$ and IFN- $\gamma$ (Fig. 5). These data indicate that the increased secretion of MCP-1 upon stimulation by proinflammatory cytokines is, at least in part, due to de novo synthesis of the protein. Stimulation of human FSC with PDGF BB (25 $\mathrm{ng} / \mathrm{ml}$ ), a mitogen for these cells, resulted in only a small increase (1.25-fold) in MCP-1 secretion. In addition, PDGF BB was also less effective than the other cytokines in increasing the expression of MCP-1 mRNA levels (data not shown). 


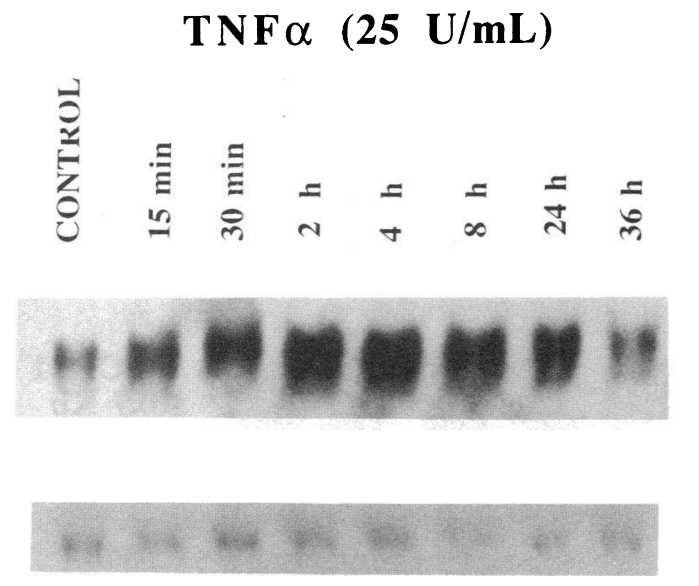

MCP-1

$-0.7 \mathrm{~Kb}$

$36 \mathrm{~B} 4$

$-1.4 \mathrm{~Kb}$

Figure 5. Northern blot analysis of MCP-1 gene expression in response to TNF $\alpha$ in human FSC. Confluent human FSC were incubated in serum-free, insulin-free medium for $48 \mathrm{~h}$ and incubated with recombinant human TNF $\alpha$ for the indicated time periods. Northern blot analysis was performed as described in the legend to Fig. 3

Analysis of FSC-conditioned medium by SDS-PAGE and immunoblotting using a highly specific antibody raised against baboon MCP-1 revealed the presence of three bands reacting with specific anti-MCP-1 antibodies (Fig. 6). The apparent molecular weight of all the three MCP-1 isoforms secreted by FSC is $<14,000$. Activation of PKC has been implicated in the early signal transduction pathway leading to MCP-1 gene expression (29). To investigate whether PKC activation is required for cytokine-mediated MCP-1 secretion and gene expression in human FSC, studies were conducted using the specific PKC inhibitor $\mathrm{H}-7$, an isoquinoline-sulfonamide derivative (30). Overnight incubation of FSC with $30 \mu \mathrm{M} \mathrm{H}-7$ did not induce any significant decrease in the 24-h production of MCP-1 by unstimulated cells (data not shown). On the other hand, when $\mathrm{H}$-7-treated cells were stimulated with either IL- $1 \alpha$, IFN- $\gamma$, or TNF $\alpha$, MCP-1 secretion was inhibited to the levels of unstimulated cells (Fig. 7). Northern blot analysis of mRNA encoding for MCP-1 isolated from FSC stimulated by proinflammatory cytokines in the presence or in the absence of

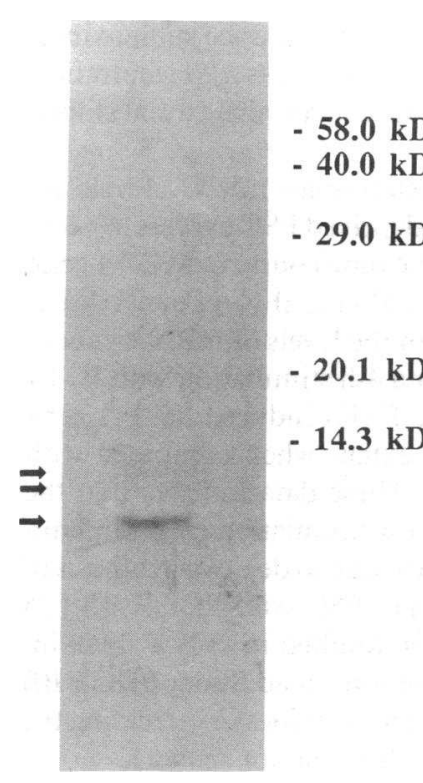

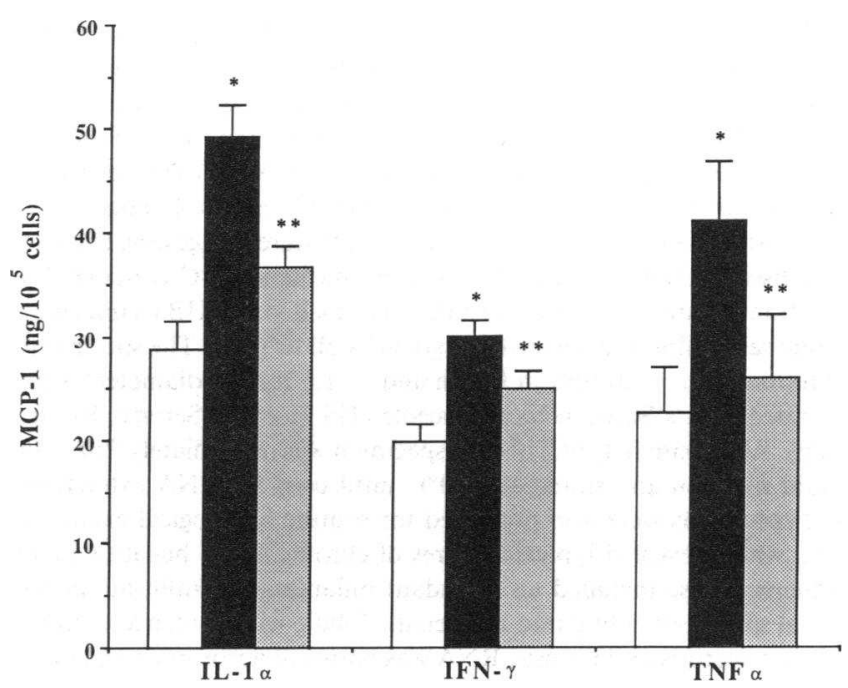

Figure 7. Effects of the protein kinase $\mathrm{C}$ inhibitor, H-7, on MCP-1 secretion by FSC. FSC had their medium changed to serum-free, insulin-free medium alone or containing $30 \mu \mathrm{m} \mathrm{H}-7$ for $10 \mathrm{~h}$. Cytokines $(10 \mathrm{U} / \mathrm{ml} \mathrm{IL}-1 \alpha, 1,000 \mathrm{U} / \mathrm{ml} \mathrm{IFN}-\gamma$, or $100 \mathrm{U} / \mathrm{ml} \mathrm{TNF} \alpha)$ were then added and cells were incubated for $24 \mathrm{~h}$. MCP-1 concentrations were assayed in cell-conditioned medium. (Open bars) Unstimulated cells; (filled bars) cytokine; (dotted bars) Cytokine + H-7. Data are mean $\pm \mathrm{SE}$ of six independent wells each assayed in duplicate (data from two separate experiments). *Significantly different from unstimulated cells $(P<0.05)$. ${ }^{*}$ Significantly different from cells stimulated in the absence of $\mathrm{H}-7(P<0.05)$.

H-7 $(30 \mu \mathrm{M})$ is shown in Fig. 8. Preincubation with the PKC inhibitor caused a decrease in the basal levels of MCP-1 mRNA, and inhibited the increase in MCP-1 gene expression induced by all three cytokines.

To evaluate the in vivo relevance of MCP-1, total RNA was isolated from liver tissue obtained from four patients with chronic active hepatitis and two subjects with normal liver structure and function. Northern blot analysis of MCP-1 gene expression is shown in Fig. 9. Normal liver showed very weak and barely detectable MCP-1 transcripts (Fig. $9 A$, lanes 1 and

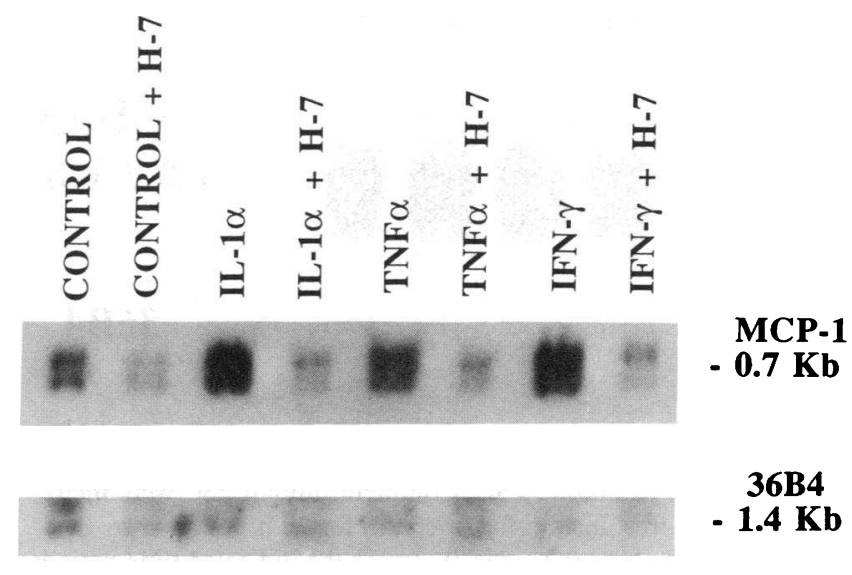

Figure 8. Effects of the protein kinase C inhibitor, H-7, on MCP-1 gene expression in human FSC. Confluent human FSC were made quiescent in serum-free, insulin-free medium for $48 \mathrm{~h}$. The protein kinase $\mathrm{C}$ inhibitor $\mathrm{H}-7$ ( $30 \mu \mathrm{M})$ was added during the last $10 \mathrm{~h}$. Cells were then incubated in the presence of cytokines for $4 \mathrm{~h}$. Northern blot analysis was performed as described in the legend to Fig. 3. 


\section{A}

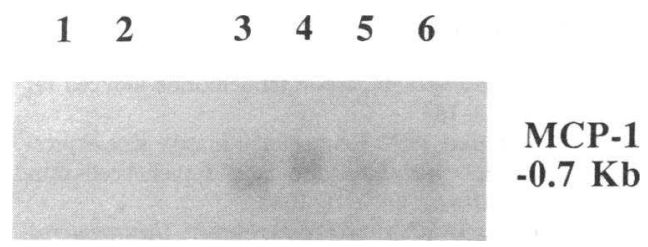

B

\section{$\begin{array}{llllll}1 & 2 & 3 & 4 & 5 & 6\end{array}$}

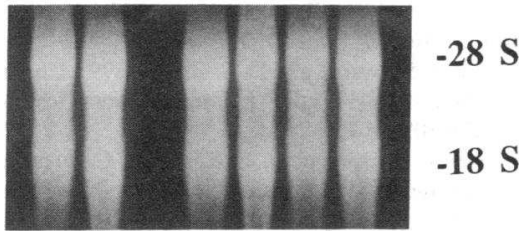

Figure 9. MCP-1 gene expression in normal and pathologic liver tissue. Liver tissue was obtained from two control subjects (lanes $l$ and 2) and four patients with chronic active hepatitis (lanes 3-6) Total RNA was prepared as described in Methods. For Northern blot analysis, $20 \mu \mathrm{g}$ of RNA was fractionated on a $1 \%$ agarose-formaldehyde gel, blotted on a nylon membrane, and hybridized with a baboon cDNA encoding for MCP-1 $(A)$. $(B)$ UV light photography of the agarose-formaldehyde gel before the transfer shows equal RNA loading.

2), whereas MCP-1 gene expression was clearly upregulated in all four patients with chronic liver disease (Fig. 9 A, lanes 3-6).

\section{Discussion}

In vivo and in vitro studies indicate that FSC play a central role in the pathogenesis of liver inflammation and fibrosis. Activation and proliferation of FSC are regulated by cytokines and growth factors released by platelets and other cells located in the hepatic sinusoid in a paracrine or autocrine fashion (31, 32). Monocyte-macrophage infiltration is observed as part of the dense cell infiltrate of chronic active hepatitis (33), a process that eventually leads to fibrosis and cirrhosis of the liver. The number of mononuclear phagocytes in the liver infiltrate has been reported to be greater in patients with more active disease, with a higher percentage of newly recruited cells (34, 35 ). In addition, these cells are in close contact with the damaged hepatocytes, suggesting the involvement of mononuclear phagocytes in the lytic attack $(33,34)$. In the present study, we show that cultured human liver FSC secrete the specific monocyte chemoattractant MCP-1, and that MCP-1 gene transcripts are expressed in these cells. The assay used is specific and sensi- tive in that it measures only MCP-1 and not other molecules that may display monocyte chemotactic activity, such as transforming growth factor- $\beta$. FSC-conditioned medium also contained chemotactic activity for monocytes in an in vitro system. The chemotactic activity is mostly due to MCP-1 since it was blocked by anti-MCP-1 antibodies. SDS-PAGE and immunoblotting demonstrated the presence of at least three different forms of MCP-1. The ability of FSC to secrete MCP-1 suggests that these cells participate in the recruitment of mononuclear phagocytes from the bloodstream. Moreover, recombinant human MCP-1 has been shown to stimulate an increase in cytosolic calcium concentration and the respiratory burst in human monocytes (36). This indicates that MCP-1 secretion by FSC may contribute not only to the recruitment, but also to the activation of freshly recruited monocytes at the site of injury. Proinflammatory cytokines like IL- $1 \alpha, \mathrm{TNF} \alpha$, and IFN- $\gamma$ strongly stimulate MCP-1 secretion by FSC. In addition, these cytokines increase the levels of mRNA encoding for MCP-1, indicating that increased mRNA transcription and/or stability contribute to the increased production of MCP-1.

To determine if MCP-1 is potentially involved in the pathogenesis of human liver disease, we examined MCP-1 gene expression in vivo in liver specimens obtained from patients with chronic active hepatitis and subjects with normal liver function and histology. MCP-1 is expressed at very low levels in normal liver, whereas it is clearly upregulated in liver tissue obtained from patients with histologically documented liver inflammation. These data indicate that increased production of this cytokine is likely to play an important role in vivo. Activated monocytes and macrophages secrete IL-1 and TNF, thus amplification of the inflammatory response is likely to occur through a paracrine loop, involving secretion of MCP-1 by FSC. In addition, the production of IFN- $\gamma$ by activated lymphocytes, the other major cellular component of chronic liver infiltrate, may represent an additional mechanism of monocyte recruitment mediated by MCP-1 secreted by FSC. FSC cultured on plastic are characterized by an activated or myofibroblast-like phenotype that is considered to reflect the behavior of FSC during liver injury, and our data on cultured cells do not provide information regarding MCP-1 production by "nonactivated" or "quiescent" cells. The data obtained in normal liver tissue indeed suggest that quiescent FSC express MCP-1 mRNA at very low levels. However, future immunohistochemical and in situ hybridization studies should help identify the site(s) of synthesis and precise cellular localization of MCP-1 in normal and pathologic liver tissue.

These data provide evidence for an additional mechanism by which FSC participate in the process of liver inflammation. We and others have recently reported that murine FSC secrete macrophage colony-stimulating factor and express mRNA encoding for this factor (37). Taken together, these findings suggest that FSC do not simply represent "target" cells, but may act as effector cells actively involved in coordinating the inflammatory response during liver injury.

Our work also provides some insights into the mechanisms that regulate MCP-1 production in human FSC. Analysis of the 5 '-flanking region of the MCP-1 gene reveals the presence of a phorbol ester-responsive element, suggesting the possible involvement of PKC in the regulation of MCP-1 gene expression (29). Indeed, pretreatment of FSC with $\mathrm{H}-7$, a potent PKC inhibitor, showed an almost complete inhibition of MCP1 production and gene expression stimulated by IL- $1 \alpha$, IFN- $\gamma$, 
or TNF $\alpha$. These findings suggest that PKC activation is likely involved in the signal transduction pathways leading to MCP-1 secretion in FSC stimulated by proinflammatory cytokines. This is the first report that suggests that PKC activation may be a prerequisite for MCP-1 secretion and gene expression in response to cytokines. It is likely that cell-specific mechanisms regulate MCP-1 secretion and gene expression since stimulation of MCP-1 gene expression by IFN- $\gamma$ in human keratinocytes does not appear to be dependent on PKC activation (38).

The results of the present study demonstrate that in cultured human liver FSC, MCP-1 secretion, and gene expression are regulated by proinflammatory cytokines, and that MCP-1 gene expression is increased during chronic liver injury in vivo. Taken together, our findings indicate that the secretion of this potent chemoattractant may participate in the recruitment and activation of peripheral blood monocytes at sites of liver injury.

\section{Acknowledgments}

We thank Kathy Woodruff for expert technical help and Olga German and Laurie Baker for typing the manuscript. We are also indebted to Drs. Stefano Milani and Giulia Pellegrini for providing us with part of the material for the in vivo experiments.

This work was supported by the VA Medical Research Service, and National Institutes of Health grants DK-33665, DK-43988, and HL26890.

\section{References}

1. Perrillo, R. P. 1992. Chronic hepatitis. In Diseases of the Liver and the Biliary Tract. G. Gitnick, D. R. LaBrecque, and F. G. Moody, editors. MosbyYear Book, Inc., St. Louis. 299-310.

2. Oppenheim, J. J., C. O. C. Zachariae, N. Mukaida, and K. Matsushima. 1991. Properties of the novel proinflammatory supergene "intercrine" cytokine family. Annu. Rev. Immunol. 9:617-648.

3. Yoshimura, T., and E. J. Leonard. 1990. Identification of high affinity receptors for human monocyte chemoattractant protein-1 on human monocytes. J. Immunol. 145:292-297.

4. Valente, A. J., D. T. Graves, C. E. Vialle-Valentin, R. Delgado, and C. J. Schwartz. 1988. Purification of a monocyte chemotactic factor secreted by nonhuman primate vascular cells in culture. Biochemistry. 27:4162-4168.

5. Graves, D. T., Y. L. Jiang, M. J. Williamson, and A. J. Valente. 1989. Identification of monocyte chemotactic activity produced by malignant cells. Science (Wash. DC). 245:1490-1493.

6. Navab, M., S. S. Imes, S. J. Hama, G. P. Hough, L. A. Ross, R. W. Bork, A. J. Valente, J. A. Berliner, D. C. Drinkwater, H. Laks, and A. M. Fogelman. 1991. Monocyte transmigration induced by modification of low density lipoprotein in cocultures of human aortic wall cells is due to induction of monocyte chemotactic protein-1 synthesis and is abolished by high density lipoprotein. $J$. Clin. Invest. 88:2039-2046.

7. Yoshimura, T., and E. J. Leonard. 1990. Secretion by human fibroblasts of monocyte chemoattractant protein-1, the product of gene JE. J. Immunol. 144:2377-2383.

8. Yoshimura, T., N. Yuhki, S. K. Moore, E. Appella, M. I. Lerman, and E. J. Leonard. 1989. Human monocyte chemoattractant protein-1 (MCP-1): full length cDNA cloning, expression in mitogen-stimulated blood mononuclear leukocytes, and sequence similarity to mouse competence gene JE. FEBS (Fed. Eur. Biochem. Soc.) Lett. 244:487-493.

9. Wake, K. 1980. Perisinusoidal stellate cells (fat storing cells, interstitial cells, lipocytes): their related structure in and around the liver sinusoids and vitamin A storage cells in extrahepatic organs. Int. Rev. Cytol. 66:303-353.

10. Blomhoff, R., and K. Wake. 1991. Perisinusoidal stellate cells of the liver: important roles in retinol metabolism and fibrosis. FASEB (Fed. Amer. Soc. Exp. Biol.) J. 5:271-277.

11. Ramadori, G. 1991. The stellate cell (Ito-cell, fat-storing cell, lipocyte, perisinusoidal cell) of the liver. Virchows Archiv. B Cell Pathol. 61:147-15.

12. Wake, K. 1988. Liver perivascular cells revealed by gold and silver impregnation methods and electron microscopy. In Biopathology of the Liver, an Ultrastructural Approach. P. Motta, editor. Kluwer Academic Publishers, Dordrecht. 23-26.

13. Pinzani, M., P. Failli, C. Ruocco, A. Casini, S. Milani, E. Baldi, A. Giotti, and P. Gentilini. 1992. Fat-storing cells as liver specific pericytes. Spatial dy- namics of agonist-stimulated intracellular calcium transients. J. Clin. Invest. 90:642-646.

14. Milani, S., H. Herbst, D. Schuppan, C. Surrenti, E. O. Riecken, and H. Stein. 1989. In situ hybridization for procollagen types I, III, and IV mRNA in normal and fibrotic rat liver: evidence for predominant expression in nonparenchymal liver cells. Hepatology. 10:84-92.

15. Nakatsukasa, H., P. Nagy, R. P. Evarts, C.-C. Hsia, E. Marsden, and S. S. Thorgeirsson. 1990. Cellular distribution of transforming growth factor- $\beta 1$ and procollagen types I, III, and IV transcripts in carbon tetrachloride-induced rat liver fibrosis. J. Clin. Invest. 85:1833-1843.

16. Maher, J. J., and R. F. McGuire. 1990. Extracellular matrix gene expression increases preferentially in rat lipocytes and sinusoidal endothelial cells during hepatic fibrosis in vivo. J. Clin. Invest. 86:1641-1648.

17. Bissel, D. M. 1992. Lipocyte activation and hepatic fibrosis. Gastroenterology. 102:1803-1805.

18. De Leeuw, A. M., S. P. McCarty, A. Geerts, and D. L. Knook. 1984. Purified rat liver fat-storing cells in culture divide and contain collagen. Hepatology. 4:392-403.

19. Ramadori, G., H. Rieder, T. Knittel, H. P. Dienes, and K.-H. Meyer Zum Buschenfelde. 1987. Fat storing cells (FSC) of rat liver synthesize and secrete fibronectin. Comparison with hepatocytes. J. Hepatol. (Amst.). 4:190-197.

20. Friedman, S. L., F. J. Roll, J. Boyles, and D. M. Bissel. 1985. Hepatic lipocytes: the principal collagen-producing cells of normal rat liver. Proc. Natl. Acad. Sci. USA. 82:8681-8685.

21. Schafer, S., O. Zerbe, and A. M. Gressner. 1987. The synthesis of proteoglycans in fat storing cells of rat liver. Hepatology. 7:680-687.

22. Davis, B. H., B. M. Pratt, and J. A. Madri. 1987. Retinol and extracellular collagen matrices modulate hepatic Ito-cell collagen phenotype and cellular retinol binding levels. J. Biol. Chem. 262:10280-10286.

23. Geerts, A., R. Vrijsen, J. Rauterberg, A. Burt, P. Schellink, and E. Wisse. 1989. In vitro differentiation of fat storing cells parallels marked increase of collagen synthesis and secretion. J. Hepatol. (Amst.). 9:59-68.

24. Valente, A., M. M. Rozek, C. J. Schwartz, and D. T. Graves. 1991. Characterization of monocyte chemotactic protein-1 binding to human monocytes. Biochem. Biophys. Res. Commun. 176:309-314.

25. Valente, A. J., S. R. Fowler, E. A. Sprague, J. L. Kelley, A. C. Suenram, and C. J. Schwartz. 1984. Initial characterization of a peripheral blood mononuclear cell chemoattractant derived from cultured arterial smooth muscle cells. Am. J. Pathol. 117:479-485.

26. Chomczynski, P., and N. Sacchi. 1987. Single-step method of RNA isolation by acid guanidinium thiocyanate-phenol-chloroform extraction. Anal. Biochem. 162:156-159.

27. Basset, P., J. P. Bellocq, C. Wolf, I. Stoll, P. Hutin, J. M. Limacher, O. L. Podhajcer, M. P. Chenard, M. C. Rio, and P. Chambon. 1990. A novel metalloproteinase gene specifically expressed in stromal cells of breast carcinomas. $\mathrm{Na}$ ture (Lond.). 348:699-704.

28. Laemmli, U. K. 1970. Cleavage of structural proteins during the assembly of the head of bacteriophage T4. Nature (Lond.). 227:680-685.

29. Shyy, Y.-J., Y. S. Li, and P. E. Kolattukudy. 1990. Structure of human monocyte chemotactic protein gene and its regulation by TPA. Biochem. Biophys. Res. Commun. 169:346-351.

30. Hidaka, H., M. Inagaki, S. Kawamoto, and S. Yasuharu. 1984. Isoquinolinesulfonamides, novel and potent inhibitors of cyclic nucleotide dependent protein kinase and protein kinase C. Biochemistry. 23:5036-5041.

31. Friedman, S. L. 1990. Cellular sources and regulation of collagen production in liver. Semin. Liver Dis. 10:20-29.

32. Bioulac-Sage, P. and S. Balabaud. 1992. Proliferation and phenotypic expression of perisinusoidal cells. J. Hepatol (Amst.). 15:284-287.

33. Paronetto F. 1988. The role of reticuloendothelial system in viral hepatitis. In The Reticuloendothelial System. M. R. Escobar and J. P. Utz, editors. Plenum Publishing Corporation, New York. 249-268.

34. Bernuau, D., E. Rogier, and G. Feldmann. 1984. In situ ultrastructural detection and quantitation of liver mononuclear phagocytes in contact with hepatocytes in chronic type B hepatitis. Lab. Invest. 51:667-674.

35. Bernuau, D., E. Rogier, and G. Feldmann. 1982. A quantitative ultrastructural analysis of the leukocytes in contact with hepatocytes in chronic active hepatitis, with a cytochemical detection of mononuclear phagocytes. Am. J. Pathol. 109:310-320.

36. Rollins, B. J., and M. Baggiolini. 1991. Recombinant human MCP-1/JE induces chemotaxis, calcium flux, and the respiratory burst in human monocytes. Blood. 78:1112-1116.

37. Pinzani, M., H. E. Abboud, L. Gesualdo, and S. L. Abboud. 1992. Regulation of macrophage colony-stimulating factor in liver fat storing cells by peptide growth factors. Am. J. Physiol. 262 (Cell. Physiol. 31):C876-C881.

38. Barker, J. N. W. N., M. L. Jones, C. L. Swenson, V. Sarma, R. S. Mitra P. A. Ward, K. J. Johnson, J. C. Fantone, V. M. Dixit, and B. J. Nickoloff. 1991 Monocyte chemotaxis and activating factor production by keratinocytes in response to IFN- $\gamma$. J. Immunol. 146:1192-1197. 